\title{
Measuring Family Support in the Elderly's Independence in Performing Activities of Daily Living (A Case Study in Medan Tuntungan District, Medan City, Indonesia)
}

\author{
Ganda Sigalingging, Selli Dosriani Sitopu \\ Department of Nursing, Faculty of Nursing, University of Darma Agung, Medan, Indonesia
}

\begin{abstract}
Family support for the elderly people plays a pivotal role in their lives. Approximately $77 \%$ of the elderly live with their families. The aging process which results in physical, mental, spiritual and psychosocial changes leads to the nature of the elderly being dependent on others in performing activities of daily living. This study aimed to determine the relationship of family support with the elderly's performing activities of daily living in the Neighborhood III and IV of Baru Ladang Bambu Sub District, Medan Tuntungan Distrcit,m Medan City, Indonesia. This analytical survey study applied cross sectional approach. Sixty one elderlies were involved as the population in this study. This study used total sampling technique wherein the number of sample equals to the number of population. In analyzing the data, chi-square test was used. The results showed that there was a relationship of family support with the elderly's performing activities of daily living with $p$ value of 0.000 . It is suggested that family members ought to spend time communicating with each other, maintaining the role of parents and caring for all family members, so that the elderly are encouraged to actively perform activities of daily living.
\end{abstract}

Keywords: Family Support, Activities of Daily Living, the Elderly

\section{Introduction}

World Health Organization (WHO) indicates that in the year 2013, Southeast Asia had the elderly population of $8 \%$ or was approximately 142 million people in number. By the year 2050 , it is estimated that the elderly population will have tripled from the year 2013. In 2000, the number of the elderly people was circa 5.3 million (7.4\%) of the total population, whereas in 2010 the number of the elderly people was 24 million (9.77\%) of the total population, and by 2020 it is estimated that the number of the elderly people will reach 28.8 million (11.34\%) of the total population in Southeast Asia [4]. Indonesia is the world's fourth most populous country. With a population of more than 200 million in $2000,7.5 \%$ or 15 million of the population are comprised of the elderly people. The results of the 2010 population census showed that the number of the elderly population in Indonesia reached 18.57 million, an increase of $7.93 \%$ in 2000 which was 14.44 million people and it was equal to the number of children under age five which was $8.5 \%$ of the total population. It is estimated that the number of the elderly population in Indonesia will continue to grow by 450,000 people per annum. Thus, according to the Central Bureau of Statistics, the number of the elderly population in Indonesia will reach 34.22 million people by 2025. The elderly population in North Sumatra Province with the age of 60 years and above has increased from 554,761 people (4.6\%) in 2005 to 765,822 people (5.9\%) in 2010 [5]. The increased number of the elderly people will have an impact on various aspects of life be it individuals, families, communities and governments. An important economic implication of the increased number of the elderly population is the increase of dependence ratio caused by the physical, psychological and social decline of the elderly. It causes the elderly unable to survive the infection and repair the damage suffered [2]. Economic development, environmental improvement and the advance of knowledge and technology, especially those of medical sciences, health promotion, disease prevention and health services result in increasing life expectancy. As a result, the number of the elderly population is increasing, and even tends to grow faster and more rapid [3].

\section{A. Aging Process}

\section{Theories}

An aging process is a natural phenomenon that all human beings experience as a result of becoming older. Hence, this phenomenon is not a disease, but rather a natural phenomenon which if not properly anticipated will bring about various problems. Aging (becoming older) is a changing process that occurs in a person as time passes by. The effect of one's aging process includes the decline in physiological, psychological, sociological and spiritual functions [1]. Aging can be defined as a series of time-related processes occurring in the adult individual that ultimately bring life to close.. Aging influences an organism's entire physiology, impacts function at all levels, and increase susceptibility to all major chronic diseases [17]. 


\section{B. Family and the Elderly}

The increased number of the elderly above-mentioned is inversely proportional to the increased number of toddlers' population. This phenomenon obviously brings in a number of consequences, including the emergence of physical, mental, social, socio-economic problems as well as the needs of health and nursing services, especially of degenerative disorders. As the elderly get older, they experience changes in brain structure which leads to deterioration in quality of life that has an impact on their independence in performing activities of daily living [2]. The independence in performing basic activities of daily living includes individuals' ability in managing or dealing with their own interests without having to rely on others. Activities of daily living typically performed by the elderly are comprised of five basic types of activities, namely eating, bathing, dressing, mobility and toilet [3]. Family is the main support system for the elderly in maintaining their health. The role of families in caring for elderly includes: 1) Maintaining or caring for the elderly and having their health checked on a regular basis. 2) Giving affection, time and attention, respect and appreciation.

Family's support and function is far reaching in the life of the elderly, wherein of around $77 \%$ of the elderly live with the family [10]. The category of family supports is comprised of 1) emotional support, 2) instrumental support, 3) informational support, 4) award support [11]. The elderly feel that their lives are complete by playing the roles of parents and also grandparents. They can play a variety of formal styles, parenting styles, the style of the wise person. Each of these styles however has respective drawbacks and advantages. Nonetheless, families may pose a frustration to the elderly. This happens if there is a communication barrier between the elderly and the family members in which the difference in generative factor plays a role. In this era of globalization, families are preoccupied with their respective jobs, as a result, less attention or support is given to the elderly. The existence of elderly is oftentimes perceived negative and regarded as the burden to the family and to the surrounding community. This fact promotes the growing assumption that growing old is tantamount to the increasing number of health issues experienced by the elderly. The elderly tend to be viewed by society as nobody but a group of sickly people. This perception arises due to the pre-conceived notion that the elderly are highly dependent and sickly people. Such negative perception does not entirely hold true. Many elderly people actually play an active role, not only in the family, but also in the surrounding community. Thus, the elderly should be regarded as individuals with intellectual, emotional, and spiritual needs, in addition to biological needs [3]. Elderly are most happy with family life especially with their children [18]. Research in many cultural settings shows that older people prefer to be in their own homes and communities, even if that means living alone [19]. Maryam, et. al., argue that family is the main support system for the elderly in maintaining his health [12].

\section{C. $\quad$ Related Literature}

A study conducted by Jein et. al. found that there is a relationship of family support with the elderly's independence in performing activities of daily living in the village of Kakara B, South Tobelo District, North Halmahera Regency with the significant relationship value $(p=0,00)$ [7]. A study conducted by Khulaifah et al., in East Sembayat Village of Manyar District, Gresik Regency on the relationship of family support with the independence of elderly in performing activities of daily living discovered that there is a relationship between family support and elderly's independence in performing activities of daily living in Sembayat Timur Village, Manyar District, Gresik Regency with the value of $p<0.05$ [8]. Indah et. al. conducted a study on the relationship of family support with elderly's independence in performing activities of daily living in Batu Village, Likupang District, North Minahasa Regency. Their study discovered that there is a relationship of family support with the independence of elderly in performing activities of daily living in Batu Village, South Likupang District, North Minahasa Regency with the value of $\mathrm{p}=0.003$ [9].

\section{A. Nature Of Study}

\section{Methodology}

The Type Of This Study Is Analytical Survey Which Uses Cross Sectional Design Aiming To Analyze The Relationship Of Family Support With Performing Activities Of Daily Living By The Elderly.

\section{B. Location Of Study}

The Study Was Conducted In The Neighborhood Iii And Neighborhood Iv Of Baru Ladang Bambu SubDistrict, Medan Tuntungan District, Medan City, Indonesia.

\section{Population And Sample}

A Total Of 61 Elderly People Were Involved As The Population In This Study. To Collect The Sample, A Total Sampling Technique Was Used Which Resulted In The Entire Population Being The Sample Of The Research. 


\section{Data Analysis Technique}

The Data Were Analyzed Using Univariate Analysis And Bivariate Analysis. This Bivariate Analysis Used Chi-Square Test With P Value A $=0,05$ With $95 \%$ Confidence Level. If $\mathrm{P}<\mathrm{A}(0,05)$, It Is Can Be Concluded That There Is A Relationship Between Family Support With The Elderly's Performing Activities Of Daily Living.

\section{A. Results of Preliminary Survey}

\section{Evaluation}

The results of preliminary field surveys conducted in neighborhood III and IV of Baru Ladang Bambu Sub District showed that there were 61 elderly people in total in both neighborhoods. Based on the results of random interviews with 10 elderly people, it was discovered that 6 of them have no difficulty in performing activities of daily living in their daily life without the help of others. It was observed that the majority of the elderly live with their families. The elderly feel happy since their existence in the family gains respect. Aside from that, the elderly also feel happy because their children and families care for them and communicate with them, they are preoccupied both at home and outside the home. However, 4 elderly people still feel that they are abandoned, unappreciated, unaccompanied by their family when they fall sick, plus they do not receive health care and tend to be bed-rested, they are not involved in family activities. They also admitted that they better die when they experience physical weaknesses that hinder their performing activities of daily living. The elderly argued that living with the family frequently arises conflict. It occurs primarily due to emotional factors, too close relationships, financial factors and different needs. It is undeniable, however, that the elderly are in need of a family when they fall sick. This causes stress both on the person caring for them and on the elderly themselves since the family's activities or works may be disrupted. However, from 10 elderly people interviewed, it was discovered that they still consider themselves healthy as long as their duties and activities of daily living are not disturbed and they are accompanied by their children and grandchildren and they can still feed themselves.

\section{B. Results of Data Analysis}

Shown below is the percentage of family support category.

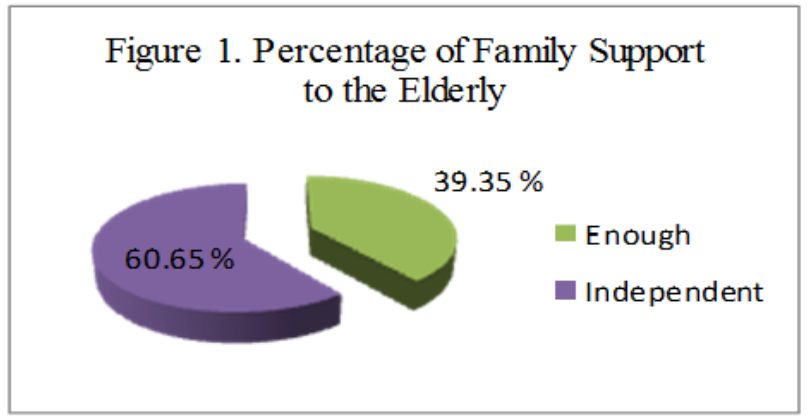

As can be seen above, family support for elderly in the category of enough is as many as 24 people $(39,35 \%)$, while family support for the elderly in performing activities of daily living in the category of independent is as many 37 people $(60,65 \%)$. The result of statistical analysis showed that there is a relationship between family support with performing activities of daily living by elderly with $p$ value $(0,000)<\alpha(0,05)$. This shows that the better the family support is given, the more independent the elderly are in carrying out activities of daily living.

\section{Discussion}

Family support is a form of interpersonal relationships given by the family to the elderly in the form of attention (affection, love and empathy) provisions of instruments (goods, services), information and assessment (information related to self-evaluation) [15]. As a person gets older, it is commonly conceived that the condition of the physical nature of multiple pathologies starts to develop, such as reduced power, low energy, missing tooth, fragile bone and all that affect the elderly in performing activities of daily living in meeting their needs [12]. This may cause disruption or physical abnormality, psychological and social functions, which leads to a state of dependence on others. If the elderly mostly depend on their families, it would be a burden to the elderly themselves, and the family would pose a burden to the government. Therefore, family support in the form of attention and affection is indispensable in supporting the health of the elderly. Health perception can potentially determine the quality of life. The elderly concept of health generally depends on personal perceptions towards functional ability. Therefore, the elderly who are engaged in the activities of daily living usually consider themselves healthy, whereas those whose activities are limited due to physical, emotional or social drawbacks may lead them to feel unhealthy. 
The result of this research found that there is a significant relationship between family support with the elderly's independence in performing activities of daily living with $p$ value $(0,000)<\alpha(0,05)$. The better the family support, the more independent the elderly are to perform activities of daily living. Despite the fact that in this research there are some elderly still lack of family support as evidenced by their struggles in doing their own activities of daily living. The elderly also said that there is no need to weigh the burden on the family members in as much as they are able to move their feet and hands. Lack of family support is mainly due to several factors, among which the family members do not recognize the health problems of the elderly and unable to provide care when the elderly are ill, the family members are occupied with their work both in the office and out in the fields. The unfulfilled socio-economics needs cause no special attention given to the elderly. There are also some families who mention that aging process goes the way it is without requiring special attention. Tradition also affects the elderly's perspective on aging and the way they receive assistance from younger family members. Elderly need assistance only when they fall ill and fall asleep on the bed. Even when the elderly fall ill, they feel embarrassed to receive help, especially in doing toilets, bathing and eating activities. Most importantly when healthy, the elderly need caring, affection, respect wherein a positive environment is maintained and each member of the family be it parents or children are recognized and appreciated of their existence and rights. The form of activities of daily living performed by the elderly includes eating, movement, personal hygiene, toilet activity, going up and down the stairs, dressing, controlling defecation, urinary control [14]. It is obvious that not all elderly are able to perform activities of daily living independently due to health issues, therefore family support comes in handy and will add to the peace of his life. However, with the support of family, it does not mean that the elderly are free from problems in life. In the life of the elderly, in order to maintain healthy physical condition, it is necessary to harmonize physical needs, psychosocial and social conditions and efforts should be made to reduce activities that are energy-consuming. As someone grows older, his physical and mental ability gradually declines. As a result, activities in their lives will somehow affect their alertness to perform activities of daily living. Therefore, the role of the family is needed to improve adequate and effective support system as well as to encourage using health services in an attempt to monitor the elderly's health prior to them falling ill. It is necessary to establish communication between family members with the elderly as well as to foster self-confidence within the elderly selves so as to motivate them to accept their limitation. The elderly should be given substitute roles as parents or grandparents. The elderly should also be involved in social activities with their fellow elderly. There are times when a person is closer and more open to his or her closest friend, making it possible to achieve the purpose of giving support [2]. One of the functions of the family is an affective function in which family members share love and safety, give attention and warmth, especially to the elderly with decreased physical ability [11]. The elderly feel that their lives is on the verge of hereafter and at the moment the affection from the surrounding family is a pleasure in itself. This suggests that the care by the family members will benefit the elderly not only physically but also psychologically.

Family support is a process that takes place lifelong, in the nature and different types of life. As such, in all stages of life cycle, social support from family members enables families to function with different abilities and reasoning. As a result, it improves family health and adaptation [15]. Thus, family support is strongly associated with supporting elderly independence in maintaining physical and psychological health so as to improve health and quality of life of the elderly. The elderly will be able to enjoy their days with peace and love that will ultimately provide a great number of benefits to all other family members.

In order for the elderly to be able to perform activities of daily living, family support is of necessity. Family support for the elderly is indispensable as long as the elderly remains knowledgeable of the intention of the support as life support [16]. As a matter of fact, however, in the elderly's life, it is often found that not all elderly are able to understand the existence of social support. This can be seen from the elderly behavior that portrays dissatisfaction, which is shown by their unwillingness to eat, bathe, walk, grumble in the toilet and tend to be disappointed. Considering the fact that family role is important, the family members must be stronger in performing family duties, especially those that are related to the elderly. One of the family's duties is that family members should be able to spot problems that typically occur in the elderly. The ability to spot this problem helps family members to deal with problems the elderly have in carrying out their activities. The family should constantly provide support in the form of concrete actions such as emotional support including expressing empathy, caring for the needs of the elderly, giving encouragement, warmth and love. In addition to that, family members could also provide information related to problems that can potentially occur in the elderly by giving advice and help solve the problems faced. Furthermore, real help support is needed in the provision of materials to maintain their health as well as to fulfill their daily needs. Apart from that, it is also necessary to give rewards to the elderly, to cultivate respect to the elderly, to look them up as the role models in the family, to engage them in making decision. ${ }^{11}$ Family members should also act as facilitators that bridge the elderly between their environment and society. A person who gets older does not necessarily mean that he has no self-dependency in performing his activities of daily living merely because he considers himself old, instead, the elderly's 
independence in carrying out their activities should be constantly maintained, since being an elderly does not necessarily mean someone is weak, helpless and dependent on others.

To sum up the discussion, this study has revealed that it is in line with Khulaifah's et. al. findings (2013) in Sembayat Timur Village, Manyar District, Gresik Regency, where they found that there is a relationship between family support with the elderly's independence in performing activities of daily living. Similarly, present study is also in line with the study conducted by Indah (2015) in Batu Village, Likupang District, North Minahasa Regency, where it was found that there is a relationship of family support with the elderly's independence in performing activities of daily living. Apart from that, this study is also supported by Husain (2013) research results in Tualango Village, Gorontalo District, in which he discovered that there is a relationship of family support with the elderly's independence [20]. This indicates that the better the support, the higher the independence of the elderly is in doing their activities.

\section{A. Conclusions}

\section{Conclusions And Suggestions}

Based on the findings of present study, it was discovered that the category of the elderly with family providing enough support is as many as 24 people $(39,35 \%)$ and the category of elderly who are independent in doing activities of daily living is as many as 37 people $(60,65 \%)$. The statistical results showed that there is a relationship of family support with performing activities of daily living. Strong support from family members is believed to be able to evoke the spirit of the elderly in fulfilling the needs of daily living leading to the elderly remaining healthy, independent and useful in his life.

\section{B. Suggestion}

It is suggested that further research touch on wider population as this study only took a small proportion of the elderly in one sub-district, in Medan city, Indonesia. Involving a variety of samples from different location would probably result in varied perspective and different results as location might have an effect on the elderly's way of living.

\section{References}

[1] Stanley, M, Beare P, G. (2007). Buku Ajar Keperawatan Gerontik Jakarta: EGC.

[2] Azizah, L. M., (2011). Keperawatan Lanjut Usia. Yogyakarta: Graha Ilmu.

[3] Nugroho, W. (2008). Keperawatan Gerontik dan Geriatrik, Edisi 3. Jakarta: EGC.

[4] Badan Pusat Statistik Indonesia. (2010). Jumlah Penduduk Indonesia. Jakarta. Accessed from http://bps.go.id

[5] Bustam, M, N. (2007). Epidemiologi Penyakit Tidak Menular, Jakarta, Rineka Cipta.

[6] Mubarak, I. W. (2006). Ilmu Keperawatan Komunitas. Jakarta, Sagung Seto.

[7] Jein, C. S., et. al. (2014). Hubungan Dukungan Keluarga Dengan Kemandirian Lansia Dalam Pemenuhan Aktivitas Sehari-Hari Di Desa Kakara B Kecamatan Tobelo Selatan Kabupaten Halmahera Utara. Buletin Sariputra, Oktober. Vol. 4 (3): $206-211$.

[8] Khulaifah, S. et. al. (2014). Hubungan Dukungan Keluarga Dengan Kemandirian Lansia Dalam Pemenuhan Activitie Daily Living Di Dusun Sembayat Timur, Kecamatan Manyar, Kabupaten Gresik. Indonesian Journal of Community Health Nursing, April.. Vol. $2(2)$.

[9] Indah, S. et. al., (2015) Hubungan Dukungan Keluarga Dengan Kemandirian Lansia Dalam Pemenuhan Aktivitas Sehari hari di Desa Batu Kecamatan Likupang Selatan Kabupaten Minahasa Utara, E-Jurnal Keperawatan (E-kp) Universitas Sam Ratulangi. Vol 3, No 2 .

[10] Fatimah. (2010). Merawat Manusia Lanjut Usia. TIM. Jakarta.

[11] Friedman, Marilyn. M. (2013) Keperawatan Keluarga Riset, Teori dan Praktik, Jakarta: EGC.

[12] Maryam, R. S, et. al. (2011). Mengenal usia lanjut dan keperawatannya. Jakarta: Salemba Medika.

[13] Marwani, A. Priyantari W. (2011). Gerontik Konsep Dasar Asuhan Keperawatan Home Care dan Komunitas.. Yogyakarta: Fitramaya.

[14] Effendy, F \& Makhfudli. (2013). Keperawatan Kesehatan Komunitas Teori dan Praktik dalam Keperawatan. Jakarta: EGC.

[15] Setiadi. (2008). Konsep dan Proses Keperawatan Keluarga. Yogyakarta : Graha Ilmu

[16] Depkes RI. (2003). Pedoman Pembinaan Kesehatan Usia Lanjut Bagi Petugas Kesehatan. Jakarta: Depkes RI.

[17] Vijg, J. (2007). Aging of the Genome; The dual role of dna in life and death. Oxford University Press.

[18] Läidmäe, V. et. al. (2012). Quality of Life of Elderly in Estonia. The Internet Journal of Geriatics and Gerontology. Vol 7. No 1, 2012. Accessed from http://ispub.com/IJGG/7/1/14023

[19] World Health Organization. Global Health and Ageing. $2011 . \quad$ Accessed from www.nia.nih.gov/sites/default/files/global_health_and_aging.pdf

[20] Husain, S. (2013). Hubungan Dukungan Keluarga Dengan Kemandirian Lansia Dalam Pemenuhan Aktivitas Sehari - hari Di Desa Tualango Kecamatan Tilango Kabupaten Gorontalo. (Unpublished Undergraduate Thesis, Universitas Negeri Gorontalo). Accessed from: http://kim.ung.ac.id/index.php/KIMFIK K/article/download/2836/2812 